\title{
Investigating Architectural Patterns of Indian Traditional Hindu Temples through Visual Analysis Framework
}

\author{
Aditya Kumar Singh ${ }^{1, *}$, Vinay Mohan Das ${ }^{1}$, Yogesh Kumar Garg ${ }^{1}$, Mohammad Arif Kamal ${ }^{2}$ \\ ${ }^{1}$ Maulana Azad National Institute of Technology, Bhopal, India \\ ${ }^{2}$ Architecture Section, Aligarh Muslim University, Aligarh-202002, India
}

Received September 19, 2021; Revised December 17, 2021; Accepted January 16, 2022

\section{Cite This Paper in the following Citation Styles}

(a): [1] Aditya Kumar Singh, Vinay Mohan Das, Yogesh Kumar Garg, Mohammad Arif Kamal, "Investigating Architectural Patterns of Indian Traditional Hindu Temples through Visual Analysis Framework," Civil Engineering and Architecture, Vol. 10, No. 2, pp. 513-530, 2022. DOI: 10.13189/cea.2022.100211.

(b): Aditya Kumar Singh, Vinay Mohan Das, Yogesh Kumar Garg, Mohammad Arif Kamal (2022). Investigating Architectural Patterns of Indian Traditional Hindu Temples through Visual Analysis Framework. Civil Engineering and Architecture, 10(2), 513-530. DOI: 10.13189/cea.2022.100211.

Copyright $\bigcirc 2022$ by authors, all rights reserved. Authors agree that this article remains permanently open access under the terms of the Creative Commons Attribution License 4.0 International License

\begin{abstract}
The Architectural image of Indian traditional temples has been fascinating the scholars since their discovery, maybe due to their mystic sensorial experience. Historians, archaeologists, artists, anthropologists, astrologists, numerologists, and exclusively architects have been exploring the mysticism either linking myths or textural tenets. The sea change has been witnessed in the architectural language of temples since the beginning of their existence to date. Since the late medieval period, this language has been deciphered in majorly Sanskrit and manifested with due authenticity. It is the colonial period wherein the various scholarships have initiated attempts to decode the mysticism of architectural language through translations \& visual transformations. Through a close review of the past researches, the paper has discerned the various constructs and approaches through which scholars have conceptualized and interpreted the architecture of Indian traditional temples. It has focused on contemporary visual frameworks for analysis of Indian traditional temples employed by scholars and the outcomes of the same. The comparatives between the building \& text put forth by scholarships were often found constructed on shaky grounds while the visual interpretations had revealed either faltered dimensional transformations or implausible geometrical propensities.
\end{abstract}

Keywords Treatise, Visual Analysis, Architectural
Language, Pattern, Aesthetics, Geometry, Hindu Temples, India

\section{Introduction}

The design of the underlined planar geometry of the Indian Traditional Hindu Temples is being derived from the metaphysical correlation to 'Vastumandala' or 'Vastupurusamandala', a magico-ritual diagram. "The square is symbolical of all cyclical time, the day, the month, the year and the wider cycle marked by the recurrence of eclipses" [1]. "The Vastumandala is the metaphysical plan of the temple primarily; its cosmological and magical implications are derived from it" [2]. According to Kramrisch, "Vastumandala is a prognostication, a forecast, and tonic of the contents, which will be built in the temple"[3] but that "this does not imply identity of the actual plan of the temple with the mandala. When the great temples were built, after the ninth century and which still stand, the drawing of the Vastupurusamandala had become an architectural rite" [4]. Whatever other expedients for the measure may have been used, whether cord or memorized mantra, the temple remains "a structure based on the rhythm of proportionate, correlated measurements [5]. The 64-square mandala has been used to layout the plan of the 
Nagara temple by the Architects during the $7^{\text {th }}$ century in Central India [6]. Sonit Bafna opines that "these trends, the idea of the governing mandala and the study of Indian architecture from an indigenous perspective can be directly under the rubrics of 'Vastu sastra or 'silpasastra' [7].

It is from these treatises, the generative geometry of mandala is drawn while the other design details were the outcome of other traditional writings on Vastu sastra such as 'Mansara', 'Mayamatam', 'Aparajita-pracham', 'Samaranganasutradhara', 'Manasollasa', 'Silpasarini', 'Silpapraksha', 'Silparatnavali', and 'Rupamandana', along with 'Puranas'. The overall architectural language of the Indian traditional Hindu temples witnesses the cultural continuity from traditional to modern and then to contemporary times through imagery, conjectural to chronicle idioms respectively [8]. "The modern and contemporary languages eschew ornamentation and the sculptures that usually adorn Hindu temples. This, however, does not make it a stripped-down version of a traditional temple nor a modern abstraction; it is an interpretation that straddles the world of collective memory and history, and the architect's subjective imagination. Moreover, it also does not insist on liturgical desires in its architecture as traditional temples would. But it is convincing that design could create innovative spaces and forms without losing the sense of exaggerated cultural continuity. This not only reflects the faith in design but also indicates the plural practices in Hindu temple building" [9]. The spatial qualities and organizational principles have rendered them timeless, the quality of continuity [10].

Scholars have been intriguing to decipher the codes behind the temple design that defines such soulful construct by applying various methodologies. This paper will review the frameworks applied by various scholars and will focus on analyzing the outcomes of these frameworks to identify the merits \& demerits of the approaches. The paper will identify the gaps in understanding the architectural patterns of the Indian traditional Hindu Temple.

\section{Architectural Patterns \& Symbolism of the Hindu Temple}

Stella Kramrisch interpreted the Traditional Hindu
Temple as the "monument of manifestation". "The temple is the concrete shape (murti) of the essence; as such it is the residence and vesture of God. The masonry is the sheath (Kosa) and body. The devotee who comes to the temple, to look at it, does so as a seer, not as a spectator" [11].

From around the seventh century, the architecture of Indian temples, broadly categorized as 'Nagara' and 'Dravida' evolved based on complex patterns related to regional traditions and cultural ethos defined in treatises. Michael Meister opined that "Traditional treatise (sastras), besides conveying the mythological context of temple building and specifying the rituals, contain elaborate classifications of temples and extensive naming of parts.

However (perhaps because no early illustrations survive, or because the texts were written by the priests and not architects), these texts have not so far, been very helpful for modern scholars seeking to understand how temples were conceived or designed" [12]. However, to understand the patterns through time, visualization is a prerequisite. So, Adam hardy substantiated the evolutionary tendencies for both Nagara and Dravida temple architecture with regional impacts such as 'Vrata', 'Valabhi', 'Latina', 'Phamsana', 'Vesara', 'Bhumija', 'Sekhari', and 'Samvarana' through systematic formal visualizations [13]. These patterns were essentially recognized by analyzing the towering part of the temple and the terms used to define the typologies are generally accepted in modern scholarship (Table-1), (Figure-1).

Table 1. Contemporary classification of Indian Traditional Hindu Temples.

\begin{tabular}{|c|c|c|c|}
\hline LANGUAGE & MODE & $\begin{array}{l}\text { GEOMETRY } \\
\text { (EVOLUTION } \\
\text { OF PLAN } \\
\text { FORM) } \\
\end{array}$ & CHRONOLOGY \\
\hline \multirow{7}{*}{ Nagara } & Latina & Orthogonal & \multirow{9}{*}{$\begin{array}{c}6^{\text {th }} \text { To } 12^{\text {th }} \text { Century } \\
\text { (500 AD to } 1100 \\
\text { AD) }\end{array}$} \\
\hline & Shekhari & Orthogonal & \\
\hline & Bhumija & Orthogonal & \\
\hline & Bhumija & Stellate & \\
\hline & Vallabhi & Orthogonal & \\
\hline & Phamsana & Orthogonal & \\
\hline & Samvarana & Orthogonal & \\
\hline \multirow{2}{*}{ Dravida } & Dravida & Orthogonal & \\
\hline & Vesara & Stellate & \\
\hline
\end{tabular}




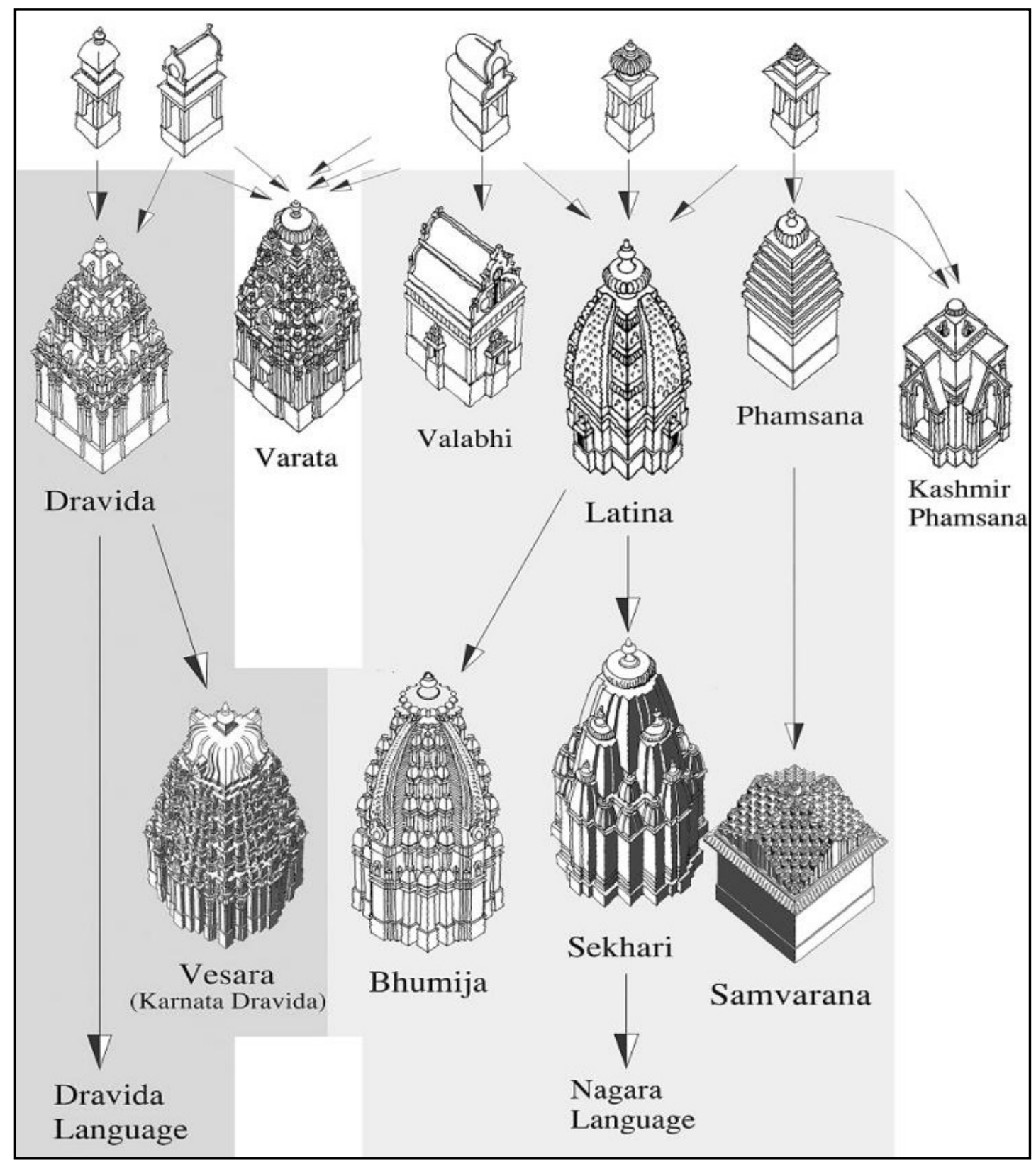

(Source: bloomsburyarchitecturelibrary.com)

Figure 1. Indian Traditional Hindu Temple Typologies

The traditional Hindu temple architecture is an openly spacious structure, with the configuration of linear symmetry on a square matrix of 'padas', with many variations and applying geometrical shapes such as squares $\&$ circles. A Hindu temple has components like a sanctuary, the 'garbhagriha', where the main deity or the image of the divine is placed. The 'garbhagriha' is surmounted by a pyramidal 'shikhara', known as 'Vimana'. Around the 'gabhagriha', a circumambulatory, 'parikrama' for ambulation is spaced. Further, a congregation hall, 'mandapa' and antechamber, 'Ardhmandapa' and a portico, 'Mukhmandapa' is laid. The architecture of the Hindu temple essentially appropriates the ideals related to dharma and the Hinduism culture. This sacred space demonstrates the connect among the mortal, divine, and the Universal 'Purusa'. These temples are a complex arrangement of artistic themes, elevations elaborately ornamented with sculptures, pillars with carvings, moulded entablatures, and standalone statues. The overall collectively defined to celebrate the human existence as per four significant principles under Hinduism - the quest for 'artha', 'kama', 'dharma', and 'moksha'.

\section{Method}

The method process provides the perspectives of various scholars towards understanding the temple design praxis. 
The paper examines the literature resources of only those scholar's perceptions that were significantly inclined towards Indian traditional temple typologies \& their respective interpretations. As such the review will draw on the visual interpretations by scholars to examine the evidence for identifying the pattern language of the Indian traditional Hindu Temples. The review has searched for the gaps in identifying the architectural pattern language embed in the Indian Traditional Hindu Temples. Figure 2, intensively details the research methodology for the analytical review. An extensive literature on Indian traditional temple typologies \& their interpretations were looked into in this review, which has given the summary of some of the key findings in terms of gaps. The gaps, though not exhaustive but provide an insight into the opportunity to interpret the architectural pattern language differently.

\section{Literature Review Process}

\section{Digital \\ Databases}

2. Print

sources

Treatise Literature search

Key Terms

Vastusastra + Puranas
Scholar's temple analysis search

\section{Key Terms}

Hindu temple design +

Visual interpretations

\section{Inclusion Criteria \\ - Language \\ (English) \\ - Academic journals (Peer- reviewed)}

\section{Exclusivity}

Literature which is not related

to Hindu temple design visual

interpretations

\section{Gap Identification \\ Summarized \\ Comparative Matrix}

Figure 2. Narrative Review Process 


\section{Scholars' Perspectives}

Ram Raz (1834) studied the maiden visual interpretation of Indian traditional Hindu Temples was through theoretical (treatise) research. Being the first scholar to analyse Hindu Architecture, he had collated ancient architectural treatises to decode the mystery of Hindu temple conception (figure-3). Through his work, published posthumously, "The Essay on the Architecture of the Hindus" the Hindu temple architecture was analyzed using scaled line drawings.

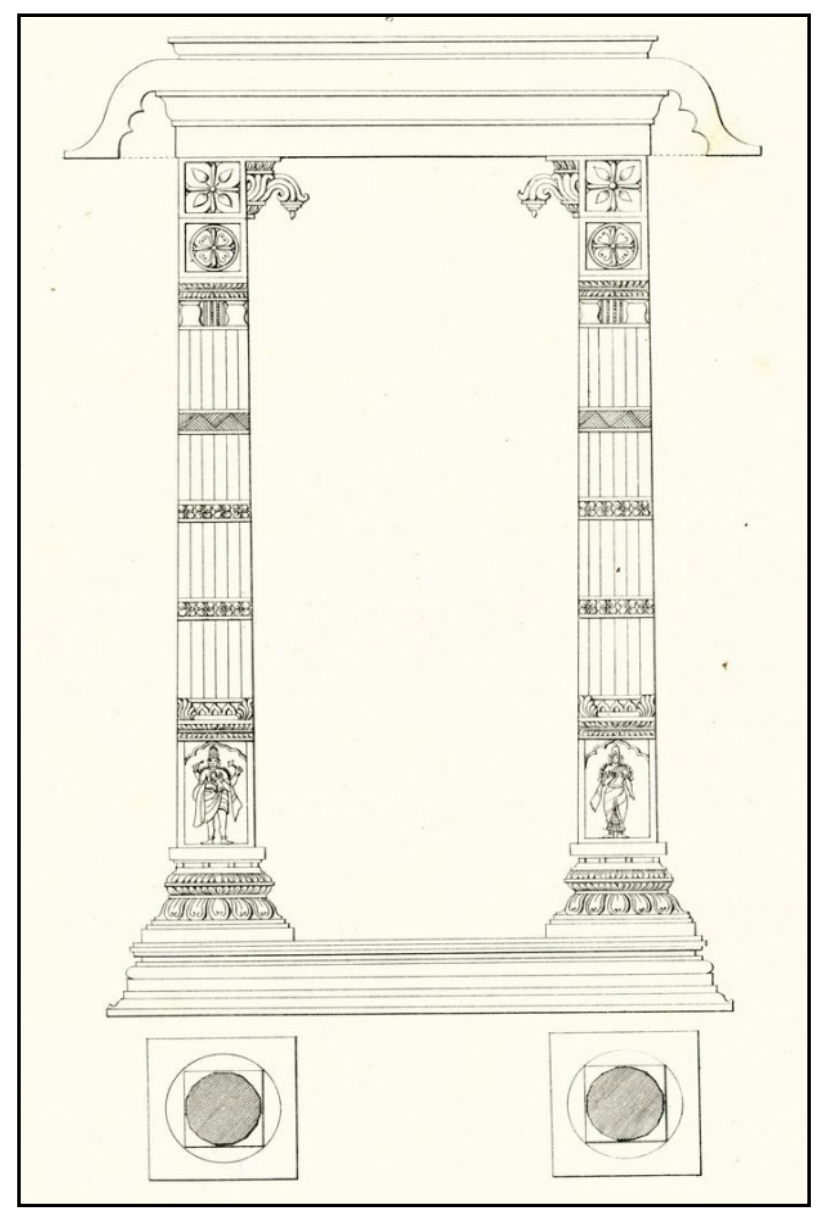

Figure 3. Indian Orders (Sectional Plan \& Elevation), Column Proportion pattern (Source: Ram Raz, Essay on the architecture of the Hindus)

The proportions were broadly explored among the various parts of the temple in relation to column dimensions. The architectural pattern was established through the language of European architectural theory showing the relationship between figure and frame. Ram Raz had visualized the mutual relationship within Indian architecture to derive architectural order imbibed within extant buildings. He inspected pillars as one of the space-making elements and conceptualized a system of proportions in relation to the European classical order which has the components such as capital, shaft \& base, instead of examining their sculptural character. Architectural drawing \& printing as representation tools were used to draw generic propositions. Efforts were made to canonize the Hindu temple architecture conception based on ordonnance. However, the methodological queries raised by Ram Raz have continued to spirit up the insights on pattern language of Indian temple architecture till contemporary times particularly the relation between buildings and texts [14]. "Ram Raz conceptualized an architectural past through assessment and analysis of architectural treatises originally written in Sanskrit, and in so doing, attempted to free a newly defined category of Hindu architecture from its Indo-Islamic context and argued for its formation through timeless concepts and trends" [15].

Ananda Kentish Coomaraswamy (1922) presented theoretical research through narratives about the aesthetics $\&$ art consciousness of Indian art \& architecture by connecting 'Vedic ritual and textural sources. He pioneered the work in the sphere of traditional Indian art philosophy. He has identified the essence of the conceptions and their antecedents in the tradition not only in the built stone but also in verbal discourse. The architectural metaphor has been questioned by asking why rather than how [16]. He has defied associational symbolism and described symbols as reflections of divine archetypes. He wrote that every artistic creation in the Indian context is a symbolic suggestion of the universe where the human is just the means of communication. As stated by him that "It is the same with architecture. Here too, the design of buildings, towns, etc. suggests and symbolizes the Universe; the site of a temple or town was laid out with reference to astrological observations; every stone had its place in the cosmic design, and the very faults of execution represented the imperfections and shortcomings of the craftsman himself." [17]. He opined that the dignity \& serenity of life is being reflected as the holistic approach to temple design \& conception. The craftsman has not expressed iconoclastic whims but poured his part of the Universe to extend his eternal beauty. These timeless commandments were documented by gurus to whom the divine divulged. And hence, the pattern language of temple architecture was seen from the lens of "know thyself".

Prasanna Kumar Acharya (1944) transcribed the selected ancient architectural treatise, 'Manasara' which is originally written in Sanskrit into graphical interpretations [18]. Owing to the apparent translation, besides the cultural and historical information, it has been recognized that this sastra contains the experience of generations \& experiments of centuries with the architecture of the Indian context. The architectural elements introduced by western influences cannot resolve the Indian habitat issues. The peculiar conditions such as dietary, clothing, etc., of the Indian context are being appreciated in this sastra, and thereby accordingly the accurate knowledge of Indian architecture is being disseminated. The work presented by the author is exhaustive i.e., each term is explained more than 'word meaning'. This is the first of its kind of 
monumental scholarly work in the domain of Indian architecture, as it looks like 'Mahabharata' of the literature on Indian Art \& architecture. The compendium contains all the terms used in the 'Mansara' along with measured drawings \& photographs and the original scope is maintained with their Sanskrit equivalents [19].

Stella Kramrisch (1946), an Art historian \& curator, had attempted to derive the theological significance by interpreting the traditional treatises (figure-4). Along with symbolic meaning, she had revealed the evolution of temple as it is created by stages from the selection of its site, through the development of its ground plan, the metaphysical explanation of its spatial organization, the choice of materials used in its construction, and the articulation of its parts according to prescribed proportional measurements to a discussion of the significant figurative images in its architectural framework The scholarly work contributes two-folds, the conceptual understanding of the Hindu temples by the pervasive connection between structure \& symbolism and the arguments for accepting the idealizations of the traditional texts as an indispensable guide for temple form [20].

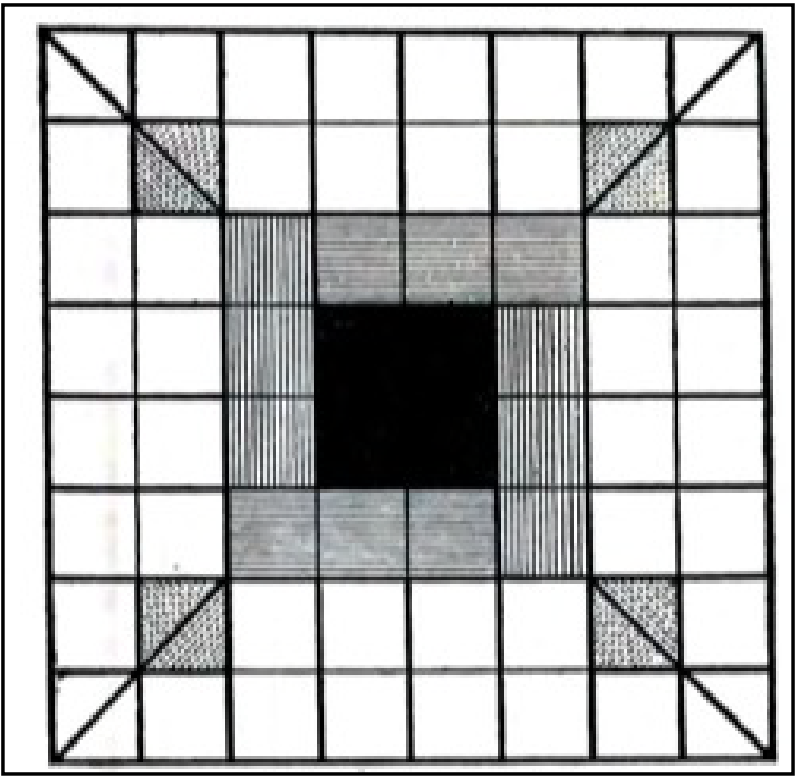

(Source: Stella Kramrisch, The Hindu Temple)

Figure 4. Type of Vastupurushamandala (Plan), Textural proportions

D.N.Shukla (1960) selected the traditional text, Bhoja's 'Samarangasutradhara', and attempted to transcribe it as Hindu Science of architecture. Likewise, Prasanna Kumar Acharya, within the 'Mansara' series, Shukla had translated the Sanskrit concepts including the study from approximately half a dozen representative texts like 'Visvakarma-prakasa', 'Aparajita-pracham' and 'Silparatna'. Shukla had successfully submitted the first systematic demarcation between the three branches of Hindu architecture: House architecture, Palace architecture, and Temple architecture [21].

Alice Boner (1962) visually analysed the Hindu sculpture compositions and transcribed the traditional
Orissan text, 'Silpa Sastra' \& 'Silpa Prakasa' [22]. The visual evidence of geometrical diagrams that has resulted from the visual analysis of sculptures revealed the inherent geometrical patterns on which the sculptures were laid in cave temples (figure-5). She identified two basic aspects of sculpture composition, firstly the space dimension which provided the static aspect of the image, and secondly, the time sequence that provided the dynamic aspect of the image. She has also ratified her findings through traditional 'Orissan' texts 'Silpa Prakasa' and 'Vastusutra Upnishad'. Her interpretations are considered to be the most precise resolution of sculptural \& architectonic forms $[23,24]$

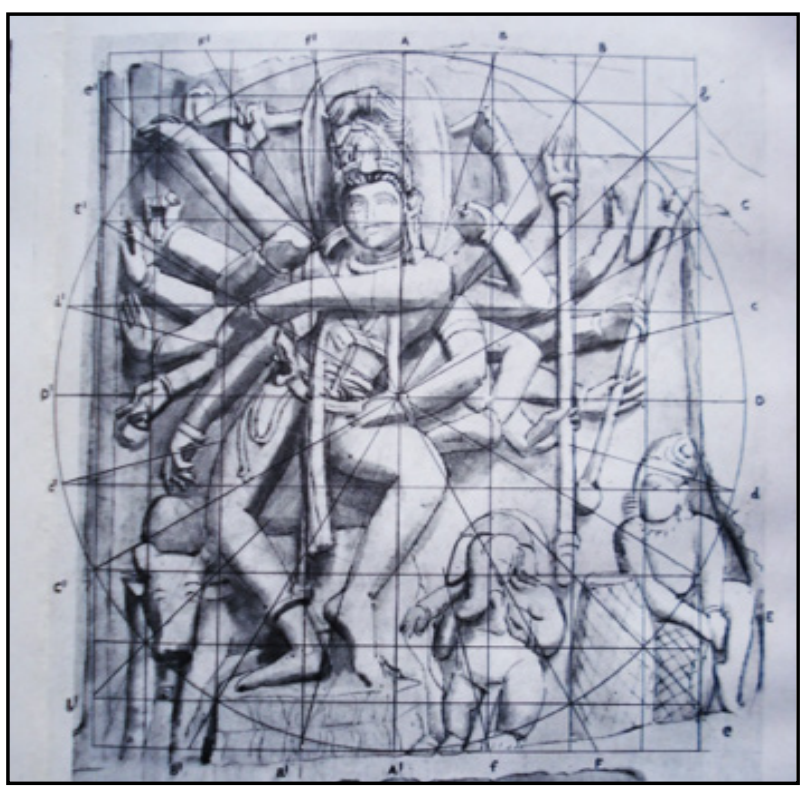

(Source: Alice Boner, Principles of composition in Hindu Sculpture-Cave temple period)

Figure 5. Space Division (Elevation), Graphical proportions

Krishna Deva (1969), an eminent scholar of Indian Art, documented the temple survey of North \& Central India by performing archaeological explorations \& related surveys. He studied the temples in the light of traditional texts and the vernacular text has been replaced by popular contemporary equivalents. He has narrated from origin to maturity and elaborated the distinctive features of the exemplary classified representative specimens of the regional styles. The concise narrative as a result of extensive, perceptive, and systematic research work appreciates the architectural skills of India which is used as a datum by the scholars [25]. In his other research, he had used the 'Vastu' texts terminology while analysing the temples, he says "Each part of the edifice and its sub-part, down to the minutest mouldings, had certain set measures and proportions which were fixed either canonically or traditionally. The Khajuraho architect had a clear concept of well-tested, standard ratios and proportions" [26].

George Michell (1977), the Hindu pantheon is being described in a simplistic manner explaining the complex mythological symbolism of Hindu Temple by this professorial fellow of University of Melbourne. A 
conscientious work on Hindu temple significance is not only illustrated but also socio-economic implications are reflected. The principles of architectural growth and stylistic evolution of both North and South Indian temples are also illuminated [27]. Further about the late medieval temples, an articulated meticulous historiographic attempt is made to understand the progressive continuity, rejuvenation, and metamorphosis in temple architecture of India [28].

Michael William Meister (1979), based on field research, incisive analysis of the conceptual and formal development of temples demonstrates that as prescribed in temple treatises, the 'Vastu Purusha Mandala', the grid (8X8) of 64-square, was employed practically in developing the ground plans of the medieval period temples (figure-6).

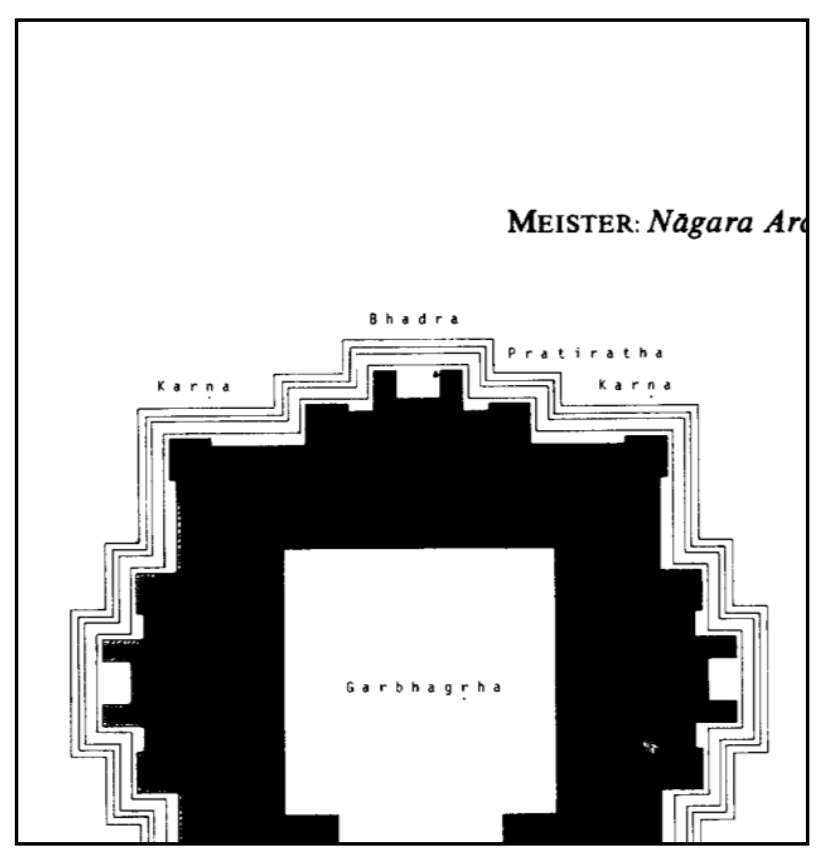

(Source: Meister, Mandala and Practice in Nagara Architecture in North India)

Figure 6. Embedded 64-square Vastu Purusha Mandala (Plan) based Orthogonal Grid proportions

He has extensively studied the Form of North Indian temples not only in his Ph.D. research work but also done extensive field study of various extant temples to reveal the GRID as the underlying geometry of planar forms of temples. He deduced that the plan form for the Hindu temple from the $5^{\text {th }}$ through $10^{\text {th }}$ century A.D. was square and that is reflected in the overall development of the 'Nagara' style temple architecture, especially in North India. However, the regional context implications interpreted this rule in different ways. So, he doctrined that "It is not clear in India that all architects at work knew the principles rather than the practice of architecture". Certainly not all temples standing accurately embody known principles in their construction. This study has found, however, that many temples do demonstrate some understanding of principles for applying the grid of the
'Vastu Mandala' to the plan of the temple. Only the master architect, however, may have understood the principles that practice embodied" [29, 30, 31].

M A Dhaky (1983), author of the collaborative work as Encyclopedia of Indian temple architecture, a mammoth project of the American Institute of Indian Studies, has meticulously essayed the genealogical content with measured layouts of temples across the Indian peninsula, a fundamental \& path-breaking contribution to the discipline. Against the theoretical perspective, it is the pioneering attempt to codify an appropriate technical terminology for Indian temple architecture within the geographical \& historical framework. The genealogical progression with characteristic architectural analysis of the North and South Indian temples from the early phase to the late medieval is elaborately edited. Patterns of patronage and the nature of artistic influence addressed in the essays also reveal pluralistic and heterogeneous cultural milieus. The focus here is on the processes that shaped the temples' contours and influenced the transmission of architectural forms spatially and temporally. The volumes consist of scaled planar layouts and photographic plates. The volumes have discussed regional and period styles where the appropriate technical terms extracted from the relevant 'vastu' text in Sanskrit were envisaged to be employed in descriptions of the buildings, reflecting as they supposedly do the perception \& language of the ancient/medieval architects and sculptors involved in their construction. The volumes are concluded with the annotated and illustrated glossary of terms. The research work has certainly imparted a new turn of eschewing the 'either or' approach. Compared with Indian Music where there is a distinctive compositional pattern so also in medieval temples and ultimately both relish the identical state of wonder. Each of the extant temples is clearly distinguished through their regional school and sub-schools along with the architectural description annotated with textural terms. The succinct description of individual temples gives a complete picture of the overall character of the regional context supported by comprehensive cross-references between text and the plates. The spatial configuration of the temples is well illustrated through scaled plan, elevation \& section, but the lack of site plan, unfortunately, refrains the reader from understanding spatial relationships of the monuments. Yet the contributions in the form of studies from 'inside' shall remain the definitive statements for guiding scholars for decades to come [32, 33, 34].

Kirti Trivedi (1989) found that "the procedures and methods used in the construction of Hindu temples bear a striking resemblance to the procedures of computer graphics, including discretization, fractalization and extensive use of recursive procedures, including self-similar iteration" (figure-7). Like computer general programs to generate outputs, the instructions given in ancient texts also generate various types of temples. An attempt has been made to draw attention to the parallel between the computer graphics procedures and the Hindu 
temple design process to explain the existing relationship between Hindu philosophy $\&$ the form of the temple. "It is proposed that Hindu temples may be viewed as three-dimensional fractal models and that the use of fractal geometry procedures has a special symbolic meaning in the generation of the forms of Hindu temples" [35].

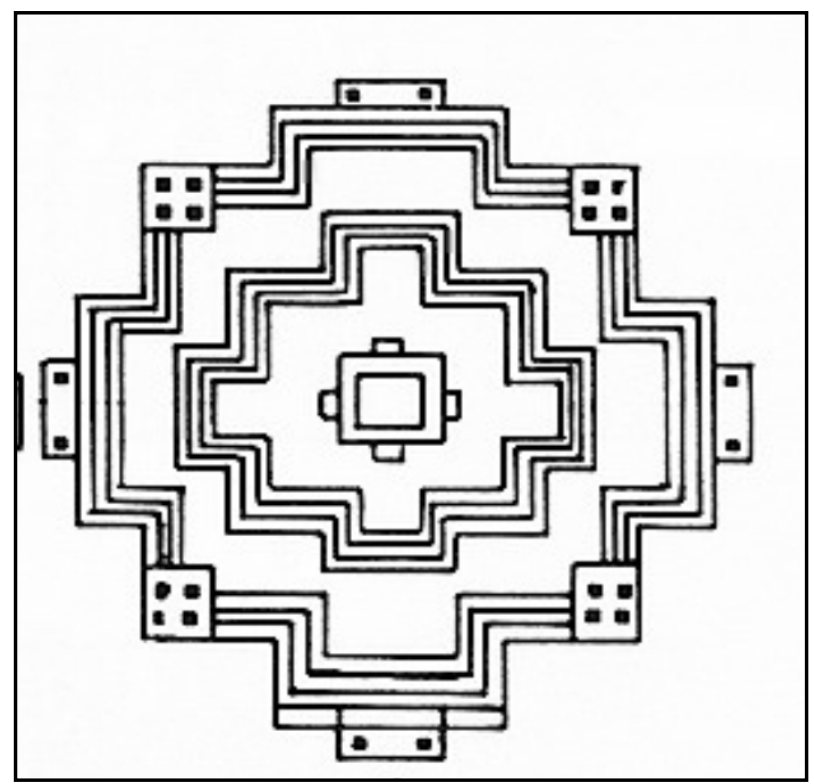

(Source: Kirti Trivedi, Hindu temples: Models of a fractal universe)

Figure 7. Ground floor geometry of temples (Plan), Fractal Proportions

Bruno Dagens (1994), dwelt upon fundamental concepts for temple design, identified perennial sources, and bridged the diverse traditions side by side of temple architecture. He has extended the studies to the Indian subcontinent and indeed the globe. According to him, the Indian temple, representing the Universe, is an amalgam of consecrated time, space, elements, and form. The Indian theology defined in the treatises is analytically interpreted encountering the various doctrines linking the Indian diaspora. Thus, reflecting the continuity \& unity of basic characteristics irrespective of diversified cultures on the globe. He has drawn the thought that the Indian temple is a representation of self-consciousness ('Siva') while transcribing the traditional text \& treatises [36]. Regarding the south Indian text Mayamata, he has remarked, "the theory of architecture we found in the Mayamata has been extrapolated from already existing monuments. In other terms, this 'Vastusastra' has been made according to some monuments and not vice versa" [37].

Adam Hardy (1995) focused on typology and explored the evolving praxis of temple architecture through a methodical decipherment of its structural components and details by observing aedicule arrangement (figure-8). His meticulous hand drawings and geometrical analysis have enabled him to decipher the language of the corpus. He has successfully exposed the finer grain of typological evolution to open up new avenues for understanding temple architecture. He has substantiated the evolutionary processes and architectural patterns by field \& visual analysis through the lens of practice. The research work also transcends the simplicity of previous approaches by refraining from complex jargon/buzzwords. His research approach is to tease out from the texts that were intended. $\mathrm{He}$ has been attempting to conflate archaeological fragments, traces of extant temples, and textural interpretations. He has illuminated the systematic analysis approach by taking Drawing \& Visualization as a tool to understand the metamorphosis of temples. The drawings are then systematically analyzed geometrically. $\mathrm{He}$ remarked that "architectural imagery did not originate in geometry, but geometrical ideas could lead to new ways of putting it together" $[38,39,40,41]$.

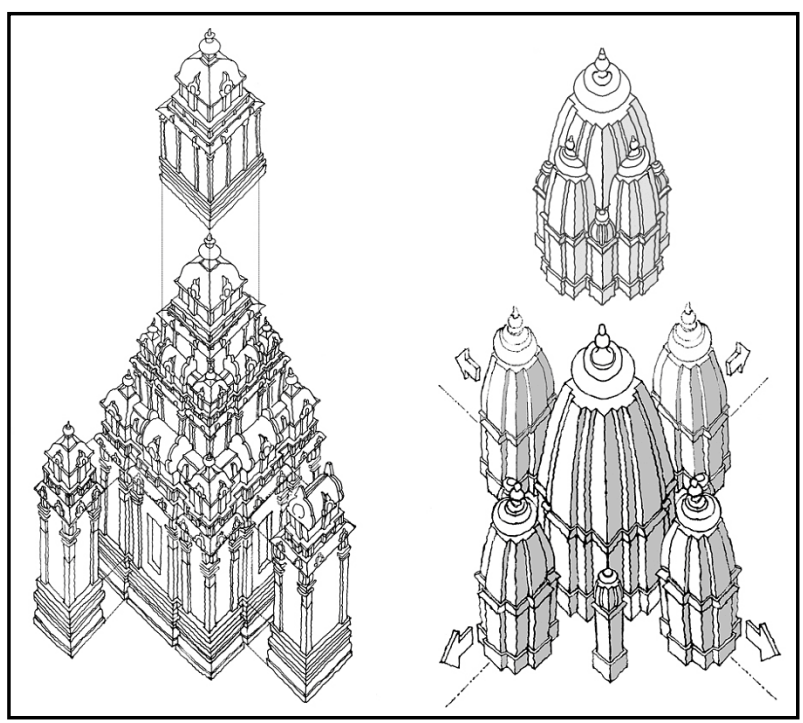

(Source: Adam Hardy, Indian Temple Architecture: Form and Transformation)

Figure 8. Evolution of temples (Axonometric view), Aedicular Proportions

Sanhita Mallick (1997) has analyzed the Dravida-Karnata typology of Indian traditional temple architecture using shape grammars. The exercise essentially consisted of beginning with a given arrangement or arrangements of certain spatial elements and identifying or constructing additional arrangements of these elements that are of the same style. It is used as a derivation method for the identification of the relational clues for the rule schema of temples [42].

Sambit Dutta (2000) has attempted to identify the geometries embed in temple extant through computational geometry and has developed a mathematical formulation of the superstructure form and a detailed three-dimensional reconstruction of a tenth-century superstructure, based upon computational reconstructions of canonical descriptions (figure-9). Through these reconstructions, the attempt provides a more complete explanation of the architectural thinking underlying superstructure form and temple ornamentation. Datta's work centers on the mediatory role of geometry in the relationship between 
formal and abstract ideas and their material realization in architecture. Using computer-aided design tools, he has investigated the geometric ideas that shaped the genesis and evolution of Indian Temple Architecture and hence translated the building through the geometric and proportional clues present in its surviving form back to its description [43, 44, 45].

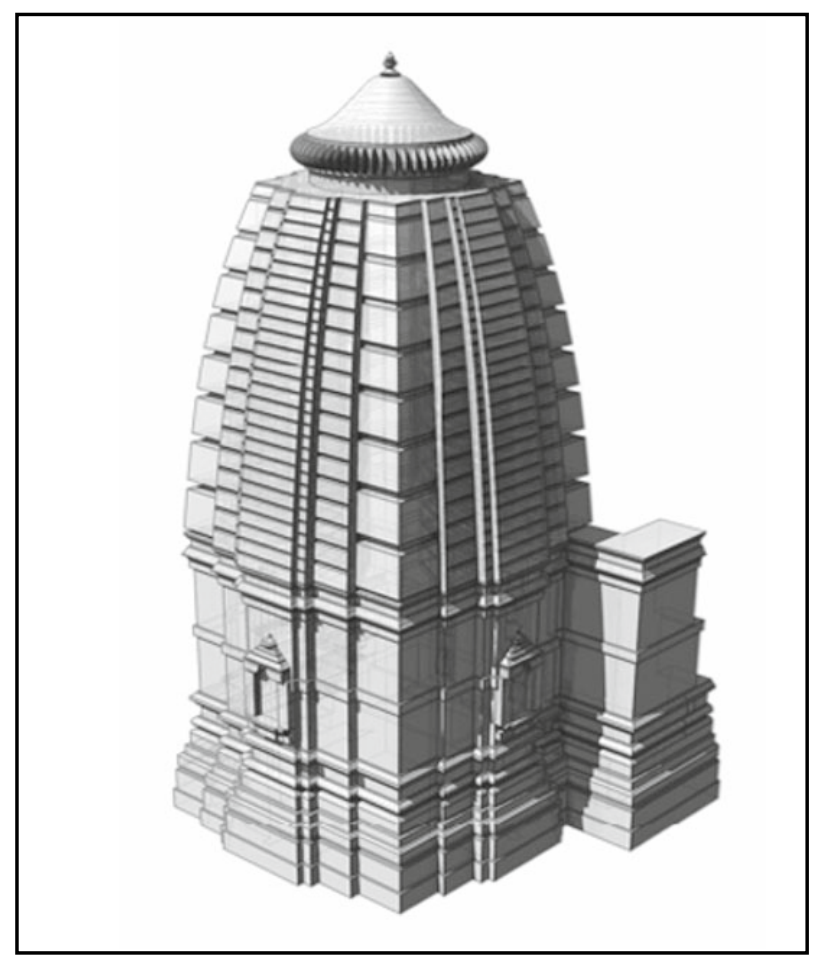

(Source: Sambit Dutta, Infinite Sequences in the Constructive Geometry of Tenth-Century Hindu Temple Superstructures)

Figure 9. Conjectural temples (Isometric View), Parametric Proportions

Sonit Bafna (2000) has researched the temple architecture merely out of curiosity regarding the role of 'Mandala', an enigmatic device and out of frustration with the uncritical manner in which the notion of this magical diagram is discussed. With the view of the Mandala as governing diagram in mid $20^{\text {th }}$ century and the connection of traditional texts for classification \& interpretations, the evidence supporting the idea of the generative mandala is drawn. It is the topological flexibility that is built within this diagram that allows it to act as an organizing and regulating guide, without giving it the additional onus of determining the dimensions of built form. He opined that Grid served the purpose of giving structure to the anthropomorphic conception of the 'Vastu Purusha Mandala' and paradoxically, to hide this structure from the inauspicious eyes of the uninitiated. It acts 'in place of the building, rather than serving as the basis of it [46].

Vinay Mohan Das (2008) has modeled \& documented the Pavilions using digital graphics, described in the 'Mayamatam', an architectural treatise of ancient India (figure-10). For architects and designers, who constantly search for new ways, the digital presentation of ancient
Indian pavilions provides a design tool for discovering new patterns to be used in contemporary architecture. This theoretical research encompasses the areas of architectural heritage, CAD, proportions, and aesthetics. The study provides a starting point for further research from the perspective of coding, shape grammar, correlation with actual built examples, and developing software to design pavilions and buildings based on the proportional principles of 'Mayamatam'. The advantage of doing CAD modeling is that it helps in easy storage, retrieval, manipulation, and editing of the objects created. The conjectural CAD model can be discussed at length before finalizing the physical reconstruction. This study can be a resource for architectural or similar institutes for conducting studies for identification, understanding, and analyzing the architecture of such sites [47, 48, 49].

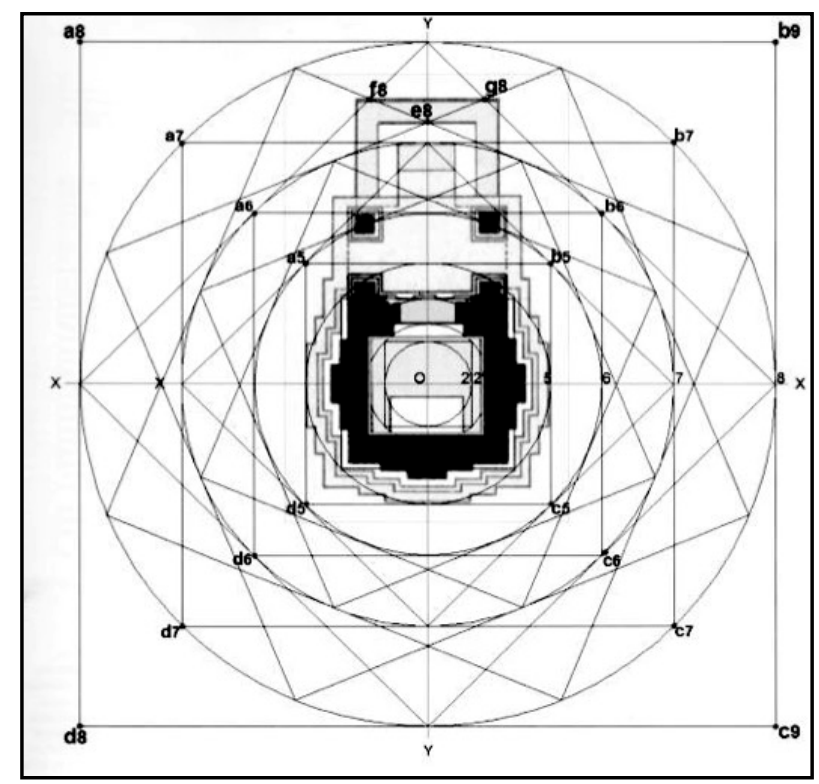

(Source: Vinay Mohan Das, Coding and Generating Complex Intercolumniation Grid Patterns for Pavilions Described in MAYAMATAM)

Figure 10. Design of Mandapa (Plan), Coding Proportions

Ananya Gandotra (2011) has attempted to study the underlying geometrical principles of temple architecture with the cohesive approach while addressing plan, elevation, and roof plan. She has developed a geometrical system of design, 'Square Circle Sequence', and applied it to selective temple precincts with insights from texts (figure-11).

The potential of modern computer technology has been exploited for effective testing of textural theories concerning measurement \& geometry. The 'Sri Yantra', frontispiece has been used to relate the underlying geometry of temples in plan \& elevation to establish a geometrical sequence model for understanding the relationship between the canonical philosophy of Hindu temple architecture and its practical applications $[50,51$, 52]. 


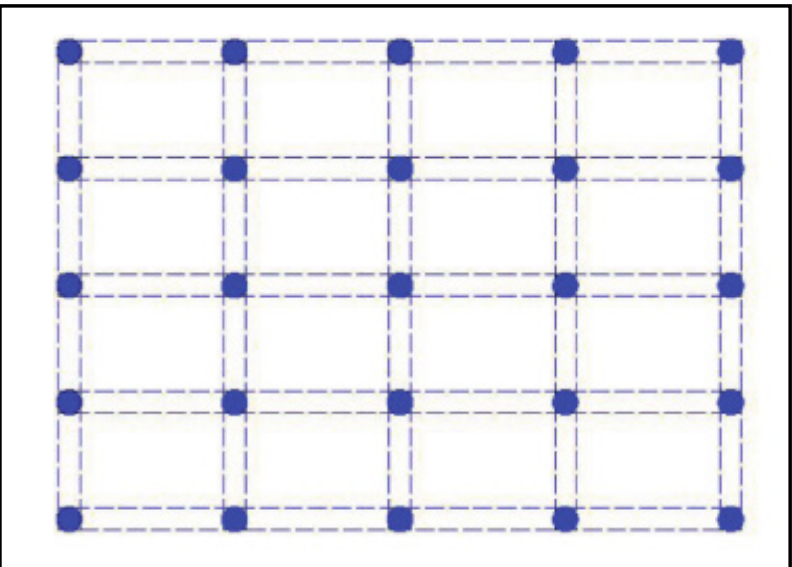

Figure 11. Temple geometry (Plan), Sequential Proportions (Source: Ananya Gandotra, Indian Temple Architecture: Analysis of Temple Plan)

\section{Results}

This section details the results of the narrative literature research on Indian Traditional Hindu Temple typologies \& their respective architectural patterns. The focus has been laid on visual interpretations only. The textural interpretations from the treatises are excluded. The following Table 2, Summarised Comparative Matrix (SCM), summarise the analysis of the literature review under the aspects of research approach, perspective, framework, propositions to identify the basis for architectural visual patterns of Indian Traditional temple for further research. 
Table 2. Summary of Analysis of Literature Review to derive visual patterns

\begin{tabular}{|c|c|c|c|c|c|c|c|c|}
\hline S. No. & YEAR & SCHOLAR & $\begin{array}{l}\text { RESEARCH } \\
\text { APPROACH }\end{array}$ & PERSPECTIVE & FRAMEWORK & PROPOSITION & VISUAL PATTERN & FIGURE NO. \\
\hline 1 & 1834 & Ram Raz & Theoretical & Textural & Drawing & Ordonnance & Columnar & 12 \\
\hline 2 & 1922 & $\begin{array}{l}\text { Ananda Kentish } \\
\text { Coomaraswamy }\end{array}$ & Theoretical & Vedic & Philosophical & Metaphysical & Symbolic & 13 \\
\hline 3 & 1944 & $\begin{array}{c}\text { Prasanna Kumar } \\
\text { Acharya }\end{array}$ & Theoretical & Epigraphical & Graphical transcription & Normative & Monographic & 14 \\
\hline 4 & 1946 & Stella Kramrisch & Theoretical & Epigraphical & Content Analysis & Normative & Textural & 15 \\
\hline 5 & 1960 & D.N. Shukla & Theoretical & Epigraphical & $\begin{array}{l}\text { Lingual \& Graphical } \\
\text { transcription }\end{array}$ & Normative & Transcriptive & 16 \\
\hline 6 & 1962 & Alice Boner & Field \& Theoretical & Sculptural perceptions & Geometrical composition & Time-space & Graphical & 17 \\
\hline 7 & 1969 & Krishna Deva & Theoretical & Anthological & Concise Narrative & Chronological & Archeological & 18 \\
\hline 8 & 1977 & George Michell & Field \& Theoretical & Metamorphic & Articulated Indology & Chronological & Historiographic & 19 \\
\hline 9 & 1979 & $\begin{array}{c}\text { Michael William } \\
\text { Meister }\end{array}$ & Field \& Theoretical & Iconographic & $\begin{array}{c}\text { Recursive Geometrical } \\
\text { Analysis }\end{array}$ & Matrix & Orthogonal & 20 \\
\hline 10 & 1983 & M A Dhaky & Field \& Theoretical & Encyclopedic & $\begin{array}{c}\text { Measured drawing } \\
\text { Analysis }\end{array}$ & Genealogical & Progressive & 21 \\
\hline 11 & 1989 & Kirti Trivedi & Theory \& Analytical & Structural & Computer Graphics & Generative & Fractal & 22 \\
\hline 12 & 1994 & Bruno Dagens & Theoretical & Epigraphical & Lingual transcription & Normative & Transcribing & 23 \\
\hline 13 & 1995 & Adam Hardy & $\begin{array}{c}\text { Field, Theoretical \& } \\
\text { Visual Analysis }\end{array}$ & Structural Coding & $\begin{array}{c}\text { Spatial Geometrical } \\
\text { analysis }\end{array}$ & Typological & Aedicular & 24 \\
\hline 14 & 1997 & Sanhita Mallick & $\begin{array}{c}\text { Field, Theoretical \& } \\
\text { Analytics }\end{array}$ & Spatial permutation & Shape Grammar & Relational & Configurational & 25 \\
\hline 15 & 2000 & Sambit Dutta & $\begin{array}{c}\text { Field, Theoretical \& } \\
\text { Analytics }\end{array}$ & Conjectural & 3D digital reconstruction & Computational & Parametric & 26 \\
\hline 16 & 2000 & Sonit Bafna & Theoretical & Generative & Imagery & Interpretative & Topological & 27 \\
\hline 17 & 2008 & Vinay Mohan Das & $\begin{array}{c}\text { Theoretical \& } \\
\text { Analytics }\end{array}$ & Mathematical Sequence & Content analysis & Logical & Coding & 28 \\
\hline 18 & 2011 & Ananya Gandotra & $\begin{array}{c}\text { Field, Theoretical \& } \\
\text { Analytics }\end{array}$ & $\begin{array}{l}\text { Digital generative } \\
\text { geometry }\end{array}$ & $\begin{array}{l}\text { Spatial Geometrical } \\
\text { analysis }\end{array}$ & Computational & Sequential & 29 \\
\hline
\end{tabular}




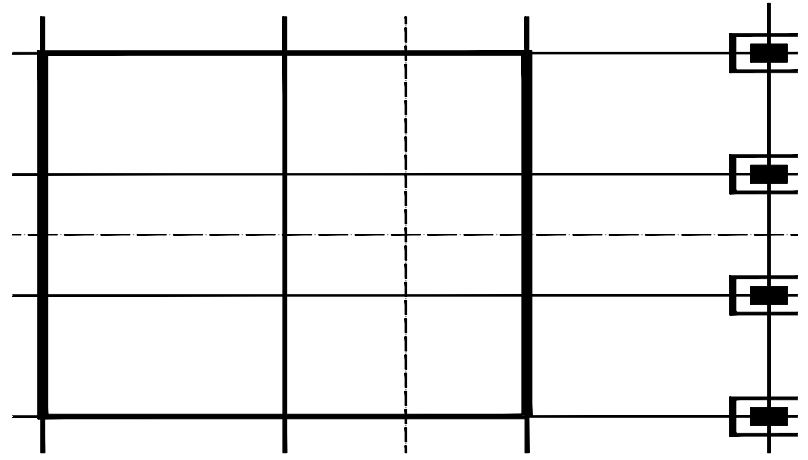

Figure 12. Columnar Visual Pattern (Source: Author)

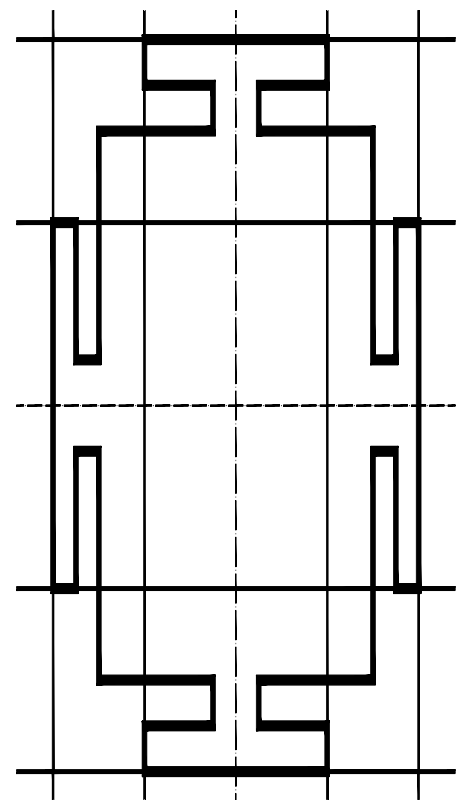

Figure 13. Symbolic Visual Pattern (Source: Author)

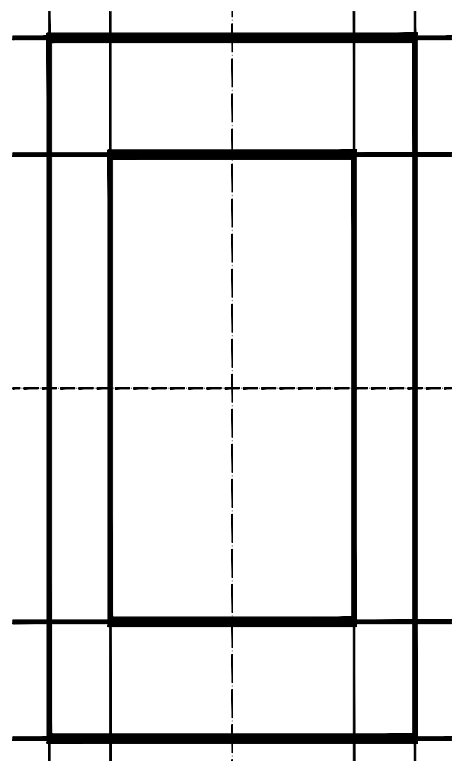

Figure 14. Monographic Visual Pattern (Source: Author)

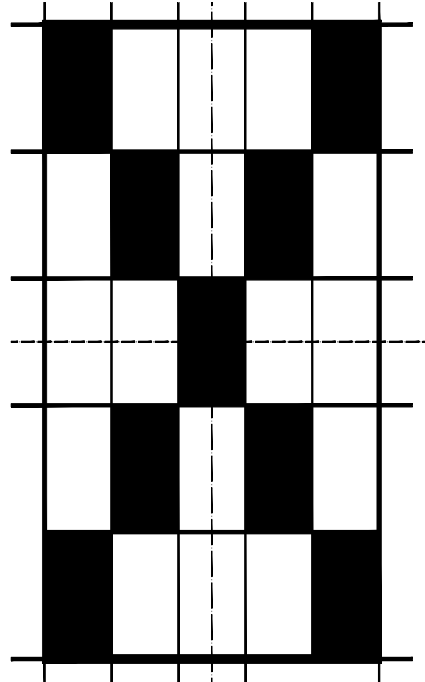

Figure 15. Textural Visual Pattern (Source: Author)

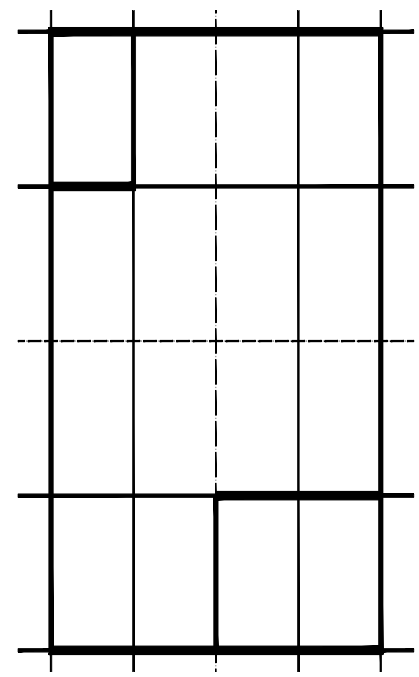

Figure 16. Transcriptive Visual Pattern (Source: Author)

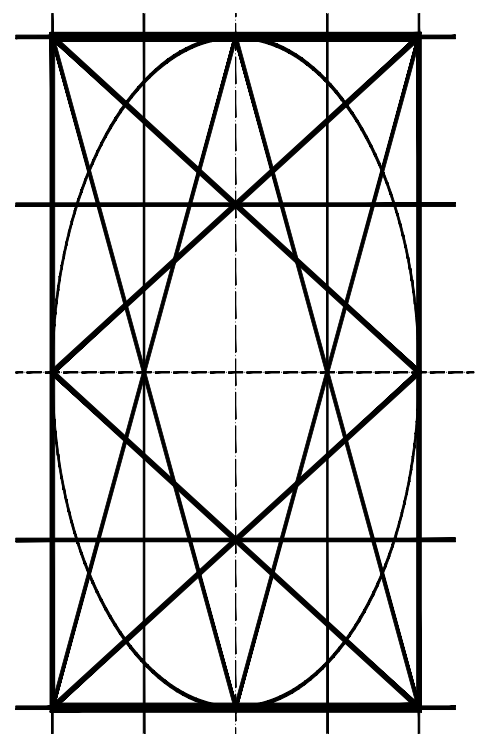

Figure 17. Graphical Visual Pattern (Source: Author) 


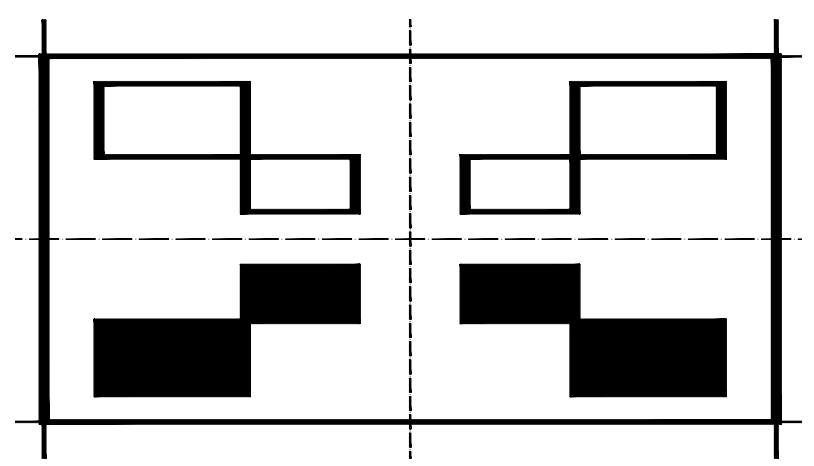

Figure 18. Archaeological Visual Pattern (Source: Author)

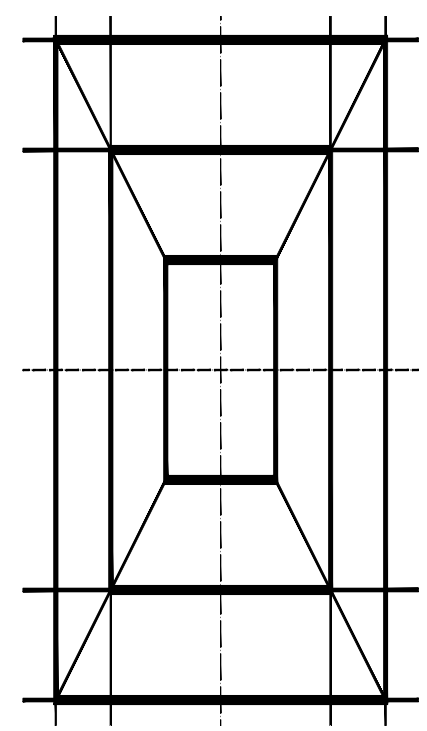

Figure 19. Historiographic Visual Pattern (Source: Author)

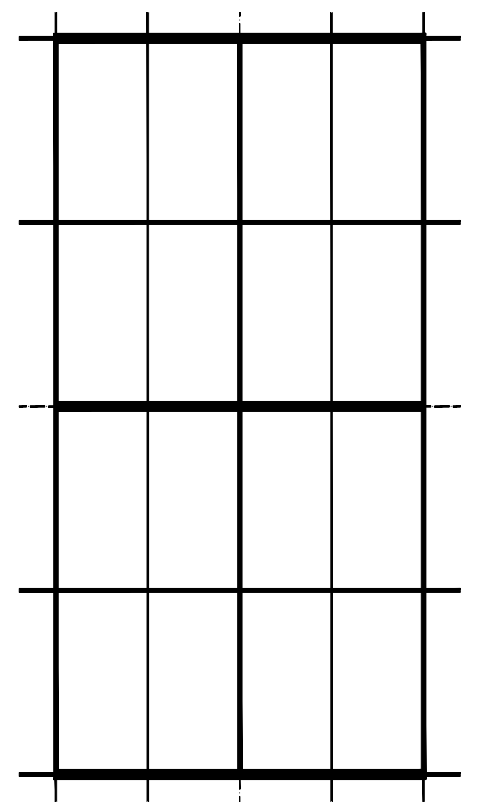

Figure 20. Orthogonal Visual Pattern (Source: Author)

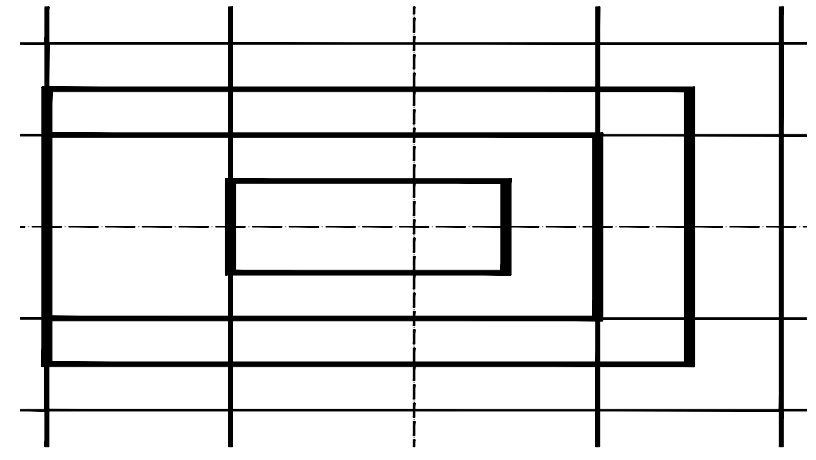

Figure 21. Progressive Visual Pattern (Source: Author)

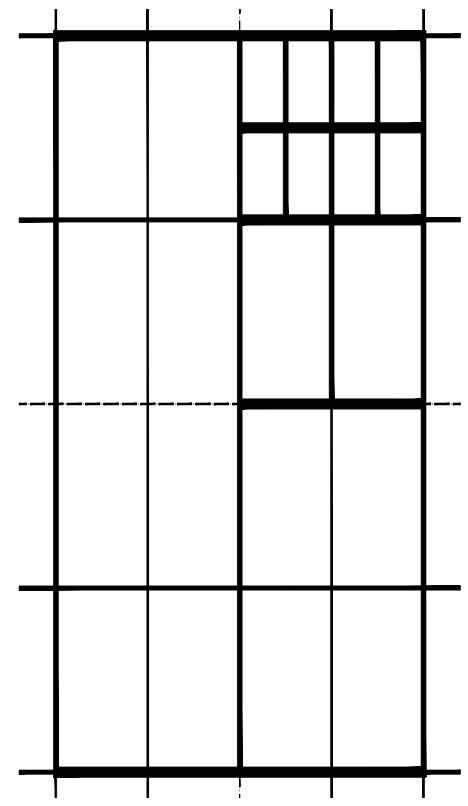

Figure 22. Fractal Visual Pattern (Source: Author)

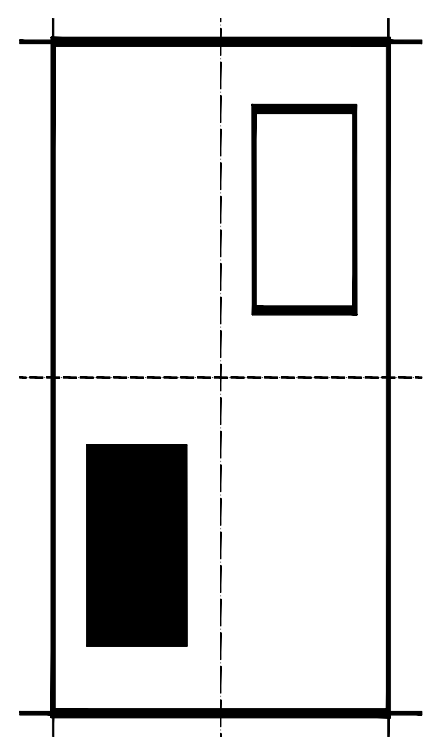

Figure 23. Transcribing Visual Pattern (Source: Author) 


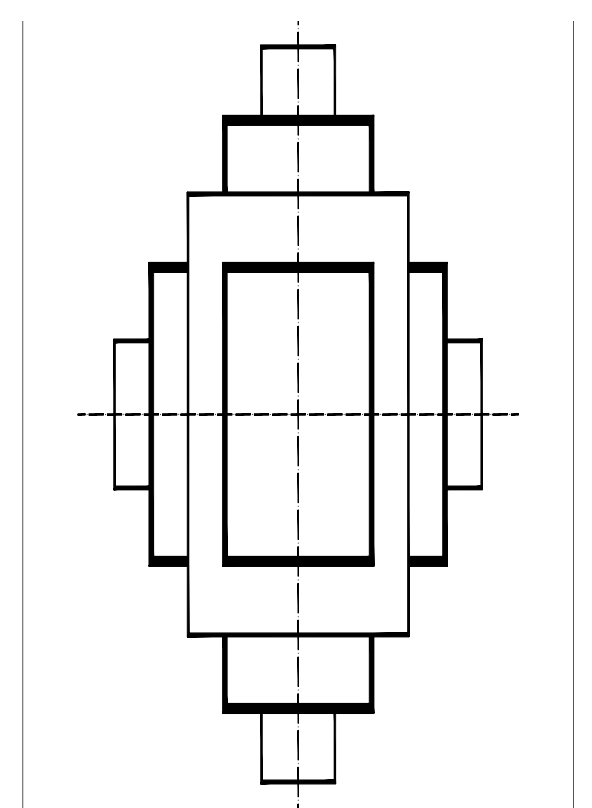

Figure 24. Aedicular Visual Pattern (Source: Author)

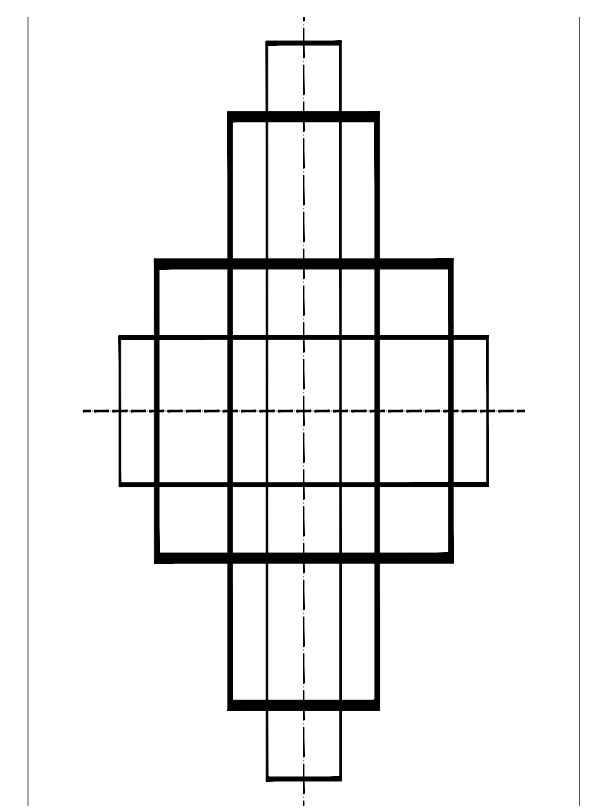

Figure 25. Configurational Visual Pattern (Source: Author)

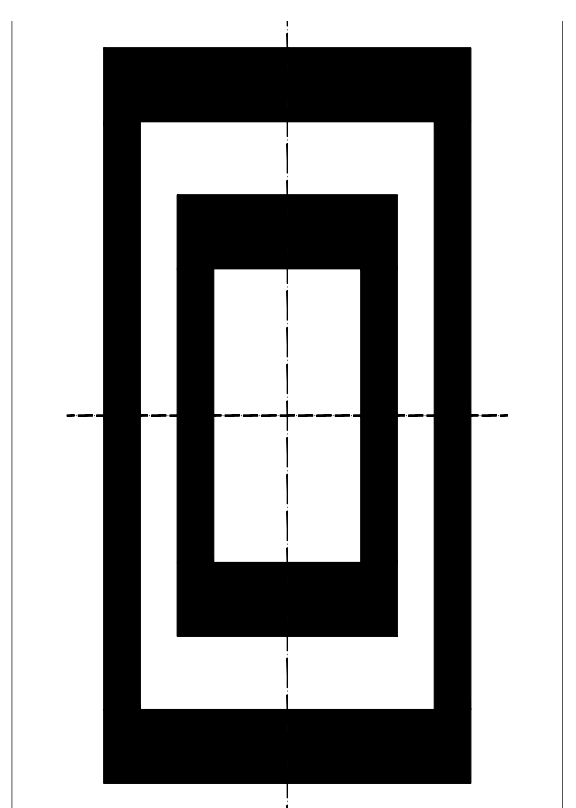

Figure 26. Parametric Visual Pattern (Source: Author)

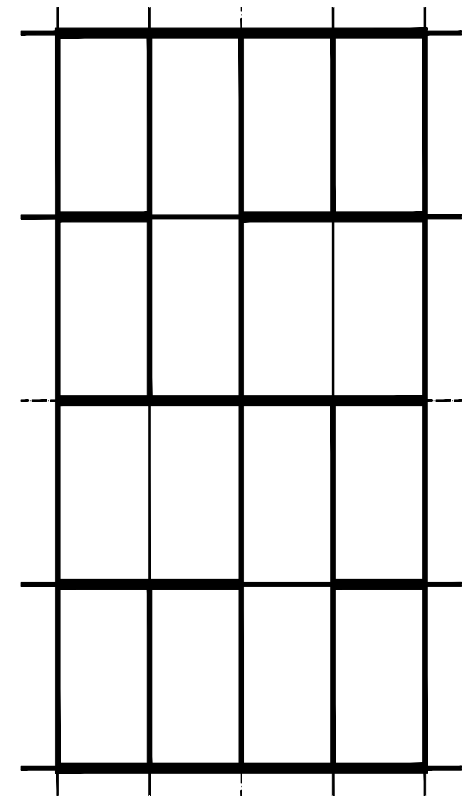

Figure 27. Topological Visual Pattern (Source: Author) 


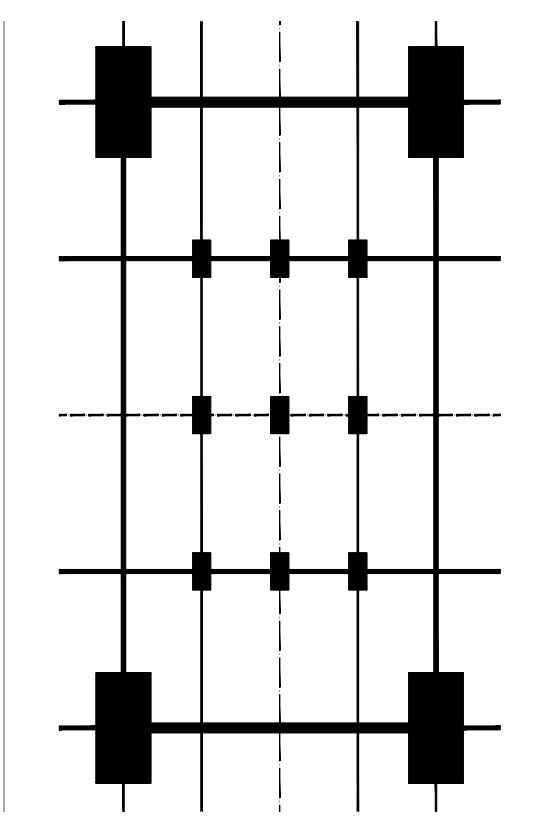

Figure 28. Coding Visual Pattern (Source: Author)

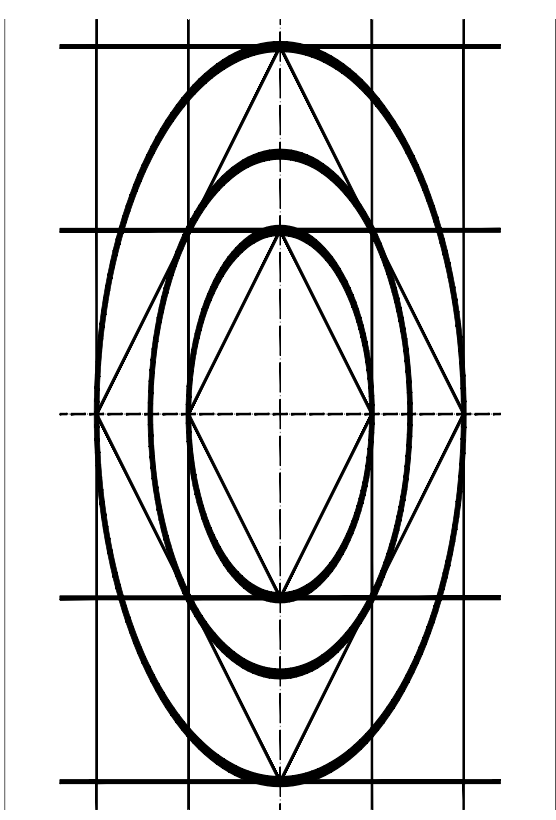

Figure 29. Sequential Visual Pattern (Source: Author)

\section{Discussion}

Indian architecture has its logic, which is exceedingly refined and precise in its details and its execution and differs in a marked degree from western norms of architectural conception. That the field of scholarship concerned with the temple architecture is moving away from the mere romantic (perceptive) sensitivities of Fergusson [53], from the archaeological collections of Cunningham [54], from pioneering classification by Percy Brown [55], a global compendium by Sir Banister Fletcher [56] and discoursed chronology by Tadgell [57] is of considerable significance. It is largely due to the impetus of line of scholarships which took traditional texts as samples of Sanskrit, to be edited, reconstructed, and discussed without benefit to practical knowledge of architecture. Stella Kramrisch provided the first breakthrough in bringing the textural approach but the intentional emphasis on the metaphysical overshadowed the true contribution towards an understanding of morphological details. Middle scholars, like Michell, Meister \& Dhaky, attempted to combine the archaeological studies with the interpretations of texts rather than using texts to reveal the temple praxis. The archaeological approach to textural studies has transformed both the archaeological \& textural study of Indian architecture and given true grounds for further architectural history. They endeavored to explore the relation of form, function, and meaning. Later scholars, such as Hardy, Dutta, Trivedi \& Das with the advent \& availability of technology in research approaches, took this combination to the next paradigm for revealing the temple architecture through mathematical, geometrical \& digital analytics. Figure 12 to 29 describes the graphical interpretations of visual patterns as summarized in Table 2 that are derived from the approaches engaged by various scholars. Such patterns reveal that there could be more permutations \& combinations for finding the underlying proportions in the planar form of the traditional temples.

The challenge to the newer scholars came as an aspiration to distinguish architecture as the esoteric domain of philosophy that influenced the efforts to read temple building praxis and treatises together as such the language of treatises i.e., Sanskrit, which today is considered as the best scientific language in the world.

\section{Conclusions}

A review of various scholarly works on Indology especially. Indian traditional temple typology has revealed various perspectives and research frameworks leading to the opportunity for research to identify the embedded architectural pattern language of sacred architecture. It is acknowledged that the review is focused only on visual framework analysis rather than on textural content analysis. It is not clear in India that all architects at work knew principles rather than simply the practice of architecture. Certainly not all temples standing accurately embody known principles in their construction. As Meister observed, "The study has found, however, that many temples do demonstrate some understanding of principles for applying the grid of the Vastu Mandala to the plan of the temple" [58]. Krishna Deva also reiterated that "the known examples follow the texts closely in the varieties of the plan and generally in composition and elevation, but differ in details of measurements and proportion" [59]. Dagens further reinforced that "ancient Indian architecture has well-defined series of proportions for plan, elevation and building elements. Proportions are prescribed for micro, meso, and macro levels which are time tested and 
are still appreciated in this age. This is mainly due to the nature of the 'Mayamatam' text itself and of its subject which allows the specialist to give an interpretation, whether it is personal or guided by the fashions of the time and place. The phenomenon is only possible because despite their doctrinaire character this treatise and others of the same group leave to architects the right to originality in the exercise of their art; in other words, the tradition is a guide more than it is a restraint" [60]. However, the underlying textural basis applied by the scholars is referral and also the text has been translated into fragments. So, as such this analytical review focused on finding the visual conceptive pattern to apply different perspectives so that temple design conception could be further explored.

\section{Acknowledgments}

The authors would like to thank all the reference sources for using their research outcomes. Further, I am indebted to my supervisor, Vinay Mohan Das for constant support and guidance.

\section{Author Contributions}

This review is part of the current Ph.D. research by Aditya Kumar Singh on Indian Traditional Temples registered with the Architecture \& Planning department of the Maulana Azad National Institute of Technology, Bhopal, INDIA. The predominant contributor to this paper is Aditya Kumar Singh while Vinay Mohan Das, Yogesh Kumar Garg and Mohammad Arif Kamal have provided indispensable guidance and critical appraisals to organize the paper, content additions, and the revisions.

\section{Conflicts of Interest}

The authors found no conflict of interest and hence declared a collaborative attempt.

\section{Glossary}

Aparajita-pracham: One of the Sanskrit treatise on science of architecture

Ardhmandapa: Transept or secondary pillared hall/pavilion

Artha: Wealth or material advantage

Bhumija: Temple spire composed of corner \& intermediate pilarettes

Dravida: South Indian style of Hindu traditional temples

Dharma: Virtues or moralities

Garbhagriha: Cella or womb-house or sanctum of temple
Kama: Love, desire or pleasure

Latina: Mono-spired with curvilinear vertical bands superstructure of temple

Mahabharata: One of the Great Sanskrit Epic of the Hindus since c. A.D. 400

Manasollasa: One of the Sanskrit treatises on science of architecture

Mandala: Diagram

Mandapa: Pillared Hall/pavilion

Mansara: One of the Sanskrit treatises on science of architecture

Mayamatam: One of the Sanskrit treatises on science of architecture

Moksha: Salvation or liberation of soul

Mukhmandapa: Pillared hall/pavilion especially at entrance

Nagara: North Indian style of Hindu Traditional temples

Orissan: Style of Hindu Traditional temples of the state

Orissa of India

Padas: Part or module

Parikrama: Circumambulation

Phamsana: Tiered pyramidal spire of temples

Puranas: A genre of Indian Literature

Purusa: Mythological image of human superimposed on Mandala

Rupamandana: One of the Sanskrit treatise on science of architecture

Samaranganasutradhara: One of the Sanskrit treatise on science of architecture

Samvarana: One of the Sanskrit treatise on science of architecture

Sastra: Science

Sekhari: Multi-spired superstructure of temple

Shikhara: Superstructure or curving spire of Nagara temple

Silpapraksha: One of the Sanskrit treatises on science of architecture

Silparatna: One of the Sanskrit treatises on science of architecture

Silparatnavali: One of the Sanskrit treatises on science of architecture

Silpasarini: One of the Sanskrit treatises on science of architecture

Silpa Sastra: The science of architecture or other cognate arts.

Upnishad: Philosophical religious texts of Hinduism

Valabhi: Rectangular wagon-vault superstructure of temple

Varata: Square pyramidal superstructure of temple

Vastu: dwelling or house

Vastumandala: house diagram

Vastupurusamandala: same as Vastumandala

Vastusastra: Manuals on science of architecture

Vedic: Relating to ancient Indian texts that inform 'Sanatan Dharma' (Eternal Order).

Vesara: Karnataka-Dravida style of Hindu traditional temples 
Vimana: Towered sanctuary of South Indian temples

Visvakarma-prakasa: One of the Sanskrit treatise on science of architecture

\section{REFERENCES}

[1] Kramrisch, S., "The Hindu Temple", Motilal Banarasidas, Calcutta, India, 1976, pp. 35.

[2] Kramrisch, S., "The Hindu Temple", Motilal Banarasidas, Calcutta, India, 1976, pp. 37.

[3] Kramrisch, S., "The Hindu Temple”, Motilal Banarasidas, Calcutta, India, 1976, pp. 58.

[4] Kramrisch, S., "The Hindu Temple", Motilal Banarasidas, Calcutta, India, 1976, pp. 228.

[5] Deva, K., "Temples of North India", National Book Trust, New Delhi, India, 1969, pp. 9.

[6] Meister, M. W., "Manḍala and Practice in Nāgara Architecture in North India", Journal of the American Oriental Society, Vol. 99, No. 2, pp. 204, 1979.

[7] Bafna, S., "On the Idea of the Mandala as a Governing Device in Indian Architectural Tradition", Journal of the Society of Architectural Historians, Vol. 59, No.1, pp. 26-49, 2000.

[8] Singh, A. K.; Das, V. M.; Garg, Y. K., "Cultural Continuity through Architecture of Hindu Temples in India”, International Journal of Emerging Technologies, Vol. 11, No. 3, pp. 01-03, 2020.

[9] Singh, A. K.; Das, V. M.; Garg, Y. K., "Cultural Continuity through Architecture of Hindu Temples in India", International Journal of Emerging Technologies, Vol. 11, No. 3, pp.12, 2020.

[10] Pandya, Y., "Concepts of Space in Traditional Indian Architecture”, Mapin Publishing, Ahmedabad, India, 2013.

[11] Kramrisch, S., "The Hindu Temple, Motilal Banarasidas, Calcutta, India”, 1979, pp.165.

[12] Meister, M. W., "Measurements and Proportions in Hindu Temple Architecture", Interdisciplinary Science Reviews, Vol. 10, No. 3, pp. 248-257, 1985.

[13] Lorenzetti, T.; Scialpi, F., "Glimpses of Indian History and Art-Reflections on the Oast, Perspectives for the Future", Proceedings on the International Congress, Sapienza Universita Editrice Rome, 2012, pp. 104-128.

[14] Raz, R., "Essay on the Architecture of the Hindu", Royal Asiatic Society of Great Britain and Ireland, London, 1834.

[15] Desai, M., "Interpreting an architectural past: Ram Raz and the treatise in South Asia", Journal of the Society of Architectural Historians, Vol. 71, No. 4, pp. 462-487, 2012.

[16] Meister, M. W., Coomaraswamy, A. K., "Essays in Architectural theory", IGNCA \& Oxford University Press, 1995.

[17] Coomaraswamy, A. K., "Fundamentals of Indian Art", The Historical Research Documentation Programme, Jaipur,
India, Vol.1, pp. 12, 1908.

[18] Acharya, P. K., "An Encyclopedia of Hindu Architecture", Oxford University Press, London, 1946.

[19] Acharya, P. K., "The architecture of Manasara: Illustrations of Architectural and Sculptural Objects. Manasara Series Volume-V", Oriental Books Reprint Corporation, New Delhi, India. 1934.

[20] Kramrisch, S., "The Hindu Temple”, Motilal Banarasidas, Calcutta, India, 1976.

[21] Shukla, D. N., "Vastu-Shastra Volume-1, Hindu Science of Architecture", Munshiram Manoharlal Publishers Pvt. Ltd., New Delhi. India. 1960.

[22] Boner, A., Sharma, S. R., "Shilpa-Shastra", Motilal Barnasidass, New Delhi, India, 1966.

[23] Boner, A., "Principles of composition in Hindu Sculpture-Cave temple period", Munshiram Manoharlal Publishers Pvt. Ltd., \& IGNCA, New Delhi, India, 1962.

[24] Boner, A., Sharma, S., Baumer, B., "Vastusutra Upanisad", Motilal Banarasidass, Delhi, India, 1986.

[25] Deva, K., "Temples of North India", National Book Trust, Delhi, India, 1969.

[26] Deva, K., "Temples of Khajuràho-2 volumes", Archaeological Survey of India, New Delhi, India, 1990, pp. 18-20.

[27] Michell, G., "The Hindu Temple: An Introduction to its Meaning and Forms", Harper \& Row New York, 1977.

[28] Michell, G., "Late Temple Architecture of India: $15^{\text {th }}$ to $19^{\text {th }}$ centuries: Continuities, Revivals, Appropriations and Innovations", Oxford University Press, New Delhi, India, 2015.

[29] Meister, M.W., "Geometry and Measure in Indian Temple Plans: Rectangular Temples", Artibus Asiae, Vol. 44, No. 4, pp. 266-296, 1983.

[30] Meister, M. W., "Maṇḍala and Practice in Nagara Architecture in North India", Journal of the American Oriental Society, Vol. 99, No. 2, pp. 204-219, 1979.

[31] Meister, M. W., "Juncture and Conjunction: Punning and Temple Architecture", Artibus Asiae, Vol. 41, No. 2-3, pp. 226-234, 1979.

[32] Meister, M. W., Dhaky, M. A., Deva, K., "Encyclopedia of Indian Temple Architecture: North India: Foundations of North Indian Style c. B.C. 250- A.D. 1100", American Institute of Indian Studies \& Oxford University Press, Delhi, India, 1988.

[33] Meister, M. W., Dhaky, M.A., "Encyclopedia of Indian Temple Architecture: North India: Period of Early Maturity c. A.D. 700-900", American Institute of Indian Studies, Delhi, India, 1991.

[34] Dhaky, M.A., "Encyclopedia of Indian Temple Architecture: North India: Beginnings of Medieval Idiom c. A.D. 900-1000", American Institute of Indian Studies \& Indira Gandhi National Centre for the Arts, Delhi, India, 1998.

[35] Trivedi, K., "Hindu temples: Models of a fractal universe", The Visual Computer, Vol. 5, No. 4, pp. 243-258, 1989. 
[36] Dagens, B., "The Indian Temple: Mirror of the world", Indira Gandhi National Centre for the Arts, New Delhi, India, 2016.

[37] Dagens, B., "The Mayamata: An Indian Treatise of Housing, Architecture, and Iconography, Sanskrit text edited and translated, 2 Vol.", IGNCA \& Motilal Banarsidas Publishers, New Delhi, India, 1994.

[38] Hardy, A., "Indian Temple Architecture: Form and Transformation", Indira Gandhi National Centre for the Arts \& Abhinav Publications, New Delhi, India, 1995.

[39] Hardy, A., "Tradition, and Transformation: Continuity and Ingenuity in the Temples of Karnataka", Journal of the Society of Architectural Historians, Vol. 60, No. 2, pp. 180-199, 2001.

[40] Hardy, A., "Theory and Practice of Temple Architecture in Medieval India: Bhoja's Samaranganasutradhara and Bhojpur Line drawings", India Gandhi National Centre for the Arts \& Dev Publishers \& Distributors, New Delhi, India, 2015.

[41] Hardy, A., "The Temple Architecture of India", John Wiley \& Sons, Chichester, UK, 2008.

[42] Mallick, S., Chatterjee, K., Merchant, A., Dasgupta, P., "Implementation of shape grammar for plan analysis", IT-Built: Information Technology for Built Environment, Elsevier, 2002.

[43] Datta S., Beynon, D., "Compositional Connections: Temple Form in Early Southeast Asia, History in Practice", Society of Architectural Historians Australia New Zealand, Geelong, Australia, 2008.

[44] Datta, S., Beynon, D., "Digital Archetypes, Adaptations of Early Temple Architecture in South and Southeast Asia", England, Ashgate, 2014.

[45] Datta, S., "Infinite Sequences in the Constructive Geometry Of Tenth-Century Hindu Temple Superstructures", Nexus Network Journal, Vol. 12, No. 3, pp. 483, 2010.

[46] Bafna, S., "On the idea of the Mandala as a governing device", Journal of the Society of Architectural Historians, Vol. 59, No. 1, pp. 26-49, 2000.

[47] Das, V. M., Garg, Y.K., "Coding and Generating Complex Intercolumniation Grid Patterns for Pavilions Described in MAYAMATAM", NEXUS-VII: Architecture \&
Mathematics, Kim Williams Books, Turin, 2008, pp. 139-152.

[48] Das, V.M., "Heritage As A Living \& Evolving Process: Graphic Transcription And Analytic Study Of Architectural Proportions In Mayamatam', New architecture \& Urbanism: Development of Indian Traditions, Cambridge Scholars Publishing \& INTBAU, India, 2010.

[49] Das, V. M., Garg, Y. K., "Digital reconstruction of pavilions described in an ancient Indian architectural treatise", ACM Journal on Computing and Cultural Heritage, Vol. 4, No. 1, pp. 16, 2011.

[50] Gandotra, A., "Indian Temple Architecture: Analysis of Temple Plan, Vol-I", Surbhi Publications, Gurgaon, India, 2011.

[51] Gandotra, A., "Temple Architecture: Analysis of Temple Elevation, Vol-II", Surbhi Publications, Gurgaon, India, 2011.

[52] Gandotra A., "Indian Temple Architecture: Shekhari Roof Plans, Vol-III", Surbhi Publications, Gurgaon, India, 2011.

[53] James, F., "History of Indian \& Eastern Architecture", Vol-I, London, 1910.

[54] Cunningham, A., "Archaeological Survey of India", Calcutta, India, 1880.

[55] Brown, P., "Indian Architecture: Buddhist and Hindu”, DB Taraporewala \& Sons, Mumbai, India, 1971.

[56] Cruickshank, D., "Sir Banister Fletcher's A History of Architecture", Butterworth Heinemann \& CBS Publishers Pvt. Ltd., New Delhi, India, 1996.

[57] Tadgell, C., "History of Architecture of India", London, 1991.

[58] Meister, W. M., "Mandala and Practice in Nagara Architecture in North India", Journal of the American Oriental Society, Vol. 99, No. 2, pp. 208, 1979.

[59] Deva, K., "Bhamija Temples: Studies in Indian Temple Architecture", AIIS, New Delhi, India 1975, pp. 91.

[60] Dagens, B., "The Mayamata: An Indian Treatise of Housing, Architecture, and Iconography, Sanskrit text edited and translated, 2 Vol.", IGNCA \& Motilal Banarsidas Publishers, New Delhi, India, 1994. 